Article (refereed)

Vivienne Richmond

'Indiscriminate liberality subverts the Morals and depraves the habits of the Poor': A Contribution

to the Debate on the Poor Law, Parish Clothing Relief and Clothing Societies in Early Nineteenth-Century England

Originally published in Textile History, 40 (1), 51-69, May 2009

You may cite this version as Vivienne Richmond, 2009. 'Indiscriminate liberality subverts the Morals and depraves the habits of the Poor': A Contribution to the Debate on the Poor Law, Parish Clothing Relief and Clothing Societies in Early Nineteenth-Century England. Textile History, 40 (1), 51-69, May 2009. ISSN 0040-4969, Online ISSN: 1743-2952: Goldsmiths Research Online.

Available at: http://eprints.gold.ac.uk/3361/

This document is the author's final manuscript version of the journal article, incorporating any revisions agreed during peer review. Some differences between this version and the publisher's version remain. You are advised to consult the publisher's version if you wish to cite from it. 


\section{Vivienne Richmond \\ 'Indiscriminate liberality subverts the Morals and depraves the habits of the Poor': A Contribution to the Debate on the Poor Law, Parish Clothing Relief and Clothing Societies in Early Nineteenth-Century England}

The agricultural workers had long hours, the pay barely enough to keep body and soul together. ... Rough food and clothes ... The struggle for respectability! $!^{1}$

Alfred Ireson, a stonemason's son, was describing Northamptonshire in the 1860 s. He looked to maternal domestic skills to keep the family respectably dressed, but to wealthier contemporaries the way in which the poor in late eighteenth and nineteenth-century England clothed themselves was something of a mystery. In 1793, for example, agricultural reformer Arthur Young examined the budgets of six families in the rural Sussex parish of Glynd (sic). He set annual expenses, including basic clothing for husband and wife, but not children, against annual incomes, including extra harvest earnings and adjusted these to take account of sickness and loss of time. In each case Young found a deficit, ranging from a relatively modest $6 s$. $2 d$. to a substantial $£ 14$ 2s. 2d., and could only assume that 'frequent and great help from the charitable and considerable farmers ... must make up the deficiencies of earnings. ${ }^{2}$

Half a century later Assistant Poor Law Commissioner Edward Tufnell found similar disparities among Kent and Sussex labourers. In one family, for example, a husband and wife with seven children were all dependent on the husband's earnings of $12 \mathrm{~s}$. a week. After deducting the cost of food, soap, candles and haberdashery the family was left with $2 \frac{1}{2} d$. per week to cover rent, heating and clothes. Where Young relied on the farmers' benevolence to make up the shortfall, Tufnell looked to enhanced earnings 'at harvest, or at odd times when more than the usual wages are earned' - and which Young had previously found inadequate but neither man ascertained whether their presumed alternative sources of income were in fact 
sufficient. $^{3}$

How the poor clothed themselves has only recently begun to attract sustained scholarly attention, most notably from Steven King who highlighted the dependence on parish clothing provision. Good pauper clothing, King claims, was a matter of civic pride, and an advertisement of how well a parish cared for its poor. The 1601 Poor Law Act had made each parish responsible for the maintenance of its poor who were unable to maintain themselves, financed through the levy of local poor rates. Some assistance, known as indoor relief, was provided in residential workhouses, but most aid came as outdoor relief, that is, in the form of cash or goods, including clothing, distributed to the poor living in their own homes. The Poor Law remained virtually unchanged for over two hundred years until the mounting cost of outdoor relief led to cutbacks and a demand for reform. The 1834 Poor Law Amendment Act aimed to abolish outdoor relief for the able-bodied and make the abhorrent workhouse the only assistance available to them. King, though, argues that in fact outdoor clothing relief continued throughout the opening decades of the nineteenth century, and even into the early years of the new Poor Law. $^{4}$

Recently in Textile History, Peter Jones set out to test King's thesis. His findings confirmed that in Hampshire and St Martin-in-the-Fields, Westminster, clothing provision remained an important parish function up to $1834 .^{5}$ In this paper, I draw on Poor Law records from Sussex and Kent to show that this was not the case nationwide. In some parts of Sussex and Kent, and potentially, therefore, elsewhere, parish clothing relief virtually ceased in the 1820s. This, I argue, was directly related to the debate about Poor Law reform which intensified from the late eighteenth century. Furthermore, the records of the Poor Law Commissioners appointed to supervise the implementation of the new Poor Law, are explicit that abolition of outdoor clothing provision was a specific goal.

Jones also notes the simultaneous existence of penny clothing societies - self-help charitable schemes - and questions why the poor joined them when 'there was little practical need ... to do so as parishes were already furnishing their ... poor with varying amounts of necessary clothing.' He also asks why the poor used clothing societies to buy the same kind of 
'practical, hard-wearing textiles' they could have obtained from the parish or 'some other charitable fund. ${ }^{, 6}$ He concludes that the attraction of clothing societies was the opportunity of independent clothing provision, and that the choice of textiles was an expression of the poor's moral attitudes toward appropriate clothing for the lower orders. I agree that the societies offered a greater degree of independent clothing provision, but I employ a close study of clothing society records to argue that they were generally intended as a replacement for, not a supplement to, parish provision. They became numerous in southern rural areas and, from mid-century, London, as parish assistance was withdrawn and the poor were left with little alternative but to join a clothing society. As such, they came to form the stable and enduring basis of clothing acquisition in the domestic economy of thousands of labouring families in the nineteenth century, yet they have received little attention. ${ }^{7}$

I further argue that, in terms of textile choice, Jones pays too little attention to the prescriptive and restrictive nature of clothing society rules and ideology. Clothing societies aimed not only at 'the amelioration of the poor's conditions alongside the reduction of the poor rates' (the crucial latter point receiving no further discussion in Jones' paper), but also at moral reform of the poor by their social superiors. ${ }^{8}$ An important factor here was the prohibition of 'finery'. Jones finally argues that 'the continued strength of the gift relationship under the Poor Law well into the nineteenth century, through the provision of good quality, hard-wearing clothes, seems to have had a significant and enduring role in fostering social cohesion throughout the troubled times during and immediately following the French wars in England. ${ }^{9} \mathrm{I}$ agree that clothing provision aimed to enhance social cohesion, but in my anthropologically-informed interpretation clothing societies also subtly changed the nature of the gift relationship to the advantage of the poor. Lastly I consider why, given their southern rural and metropolitan popularity, clothing societies were rarely found in northern, especially industrial, districts to suggest avenues for further research.

'SENT OUT NAKED IN ALL SEASONS AND WEATHER': THE DECLINE OF OUTDOOR CLOTHING RELIEF In 1783-85 annual poor relief expenditure in England and Wales averaged £2,000,000. 
By $1829-33$ it had risen to $£ 6,700,000$ via a peak in 1818 of over $£ 7,800,000 .^{10}$ Poor rates soared particularly in the over-populated wheat-producing agricultural areas Mark Blaug termed 'Speenhamland counties,' where parish doles, based on family size and the price of bread, supplemented low wages. The period from 1813 to the end of the 1830 s was especially bleak for English agriculture and in Speenhamland counties poor relief per head was generally higher than elsewhere. In 1802 it averaged 12s. in the former compared with 8s. in non-Speenhamland counties, rising to $13 s$. $8 d$. and $8 s$. $7 d$. respectively by 1831 , with Sussex the highest-spending county throughout. ${ }^{11}$

Parliamentary Reports on the Poor Laws in 1817 and 1818 demanded a reduction in poor relief spending. ${ }^{12}$ In Sussex, parish clothing for the outdoor poor was one area where savings were made. For example, in Rotherfield, with a population of just over two thousand, the Request Books show that in February 1811 the overseers considered a typical twenty-seven requests for clothing and granted two-thirds. ${ }^{13}$ By January 1813 requests had increased to fiftyone and again two-thirds were granted. The clothing given was robust working dress, including shoes, breeches, gowns, stockings, petticoats, shirts, waistcoats, round frocks (smocks), great coats and bed gowns. But in the same month a decade later, 1823, only three requests for clothing were granted. ${ }^{14}$ Local opposition to clothing relief was evidenced by landowner Lord Sheffield who in 1815 wrote to the parish officers in Fletching, eleven miles from Rotherfield, insisting they had no power to relieve the poor out of the workhouse with any kind of clothing. Assistance, he said, should come from charitable sources, and be directed towards the 'industrious and well-disposed poor. ${ }^{15}$

This rise and fall in parish clothing provision was mirrored in Deptford, on the London border of north-west Kent. A semi-urban district with a population of between twelve and thirteen thousand, Deptford was quite different from rural Rotherfield. As home to the Royal Dockyard and the Navy victualling depot, the French wars brought some employment to Deptford, but also rising prices and in the early years of the nineteenth century, a steep rise in poor-rates. ${ }^{16}$ In the parish of St. Paul's, during the first quarter of 1810, the Overseers' Minutes show thirty-five items of clothing - shoes, shifts, petticoats and shirts - granted in outdoor relief. As in Rotherfield, 
outdoor clothing relief in St. Paul's reached a peak in this decade, rising to 211 items by the same quarter in 1817. For the same quarter in 1825 sixty-five items were granted, and between December 1825 and January 1827 a total of just eleven items were distributed as outdoor clothing relief. ${ }^{17}$

At the end of the Napoleonic Wars in 1815, a combination of inflated prices and static or depressed wages throughout the country put new clothing even further beyond the reach of many. The increased cost of clothing is illustrated by the contracts to supply drapery to the workhouse at St. Paul's, Deptford. For example, between 1809 and 1813 men's blue kersey cloth coats were supplied for $7 \mathrm{~s}$. or $7 \mathrm{~s}$. $6 \mathrm{~d}$. each, but by early 1816 the price had risen to $14 \mathrm{~s}$. $6 d$. Similarly, men's drab breeches rose from $5 s$. in 1813 to $7 s$. $4 d$. during 1815-16 and while these dropped to a stable $4 s$. to $4 s$. $6 d$. during 1823-7, other garments remained expensive. By 1822 the cost of men's coats had decreased only to a steady $13 \mathrm{~s}$. to $13 \mathrm{~s}$. $6 d$., still nearly twice their price a decade earlier. ${ }^{18}$ It is reasonable to link the rise in parish clothing provision with the corresponding rise in clothing prices, but the lack of a corresponding fall in price as provision declined, combined with the strictures of the Parliamentary Reports, suggests this was linked to a determined effort to reduce outdoor relief.

By 1832 virtually the only clothing given by the Rotherfield overseers as out-relief was for boys and girls starting out in service, partly as a bargain made with prospective employers to relieve the parish of other maintenance costs. The Rotherfield Request Book records, for example, that in January 1823, Mrs. Ovenden of Salters Green agreed to 'keep Lois Frost till Ladytide if the Parish will allow her Clothes as others. Granted. ${ }^{19}$

The abolition of outdoor clothing relief was warmly embraced by the Poor Law Commissioners who, by 1839 , were claiming that across the country the 'practice of allowing clothing to adult paupers out of the workhouse appears to be so rare, as not to call for any remarks' on their part. ${ }^{20}$ They were exaggerating; implementation of the reforms was uneven and the main target of the 1834 Amendment Act was the rural south. ${ }^{21}$ But there is no doubting the Commissioners' intentions. By 1846 they were condemning even the provision of outrelief clothing to boys and girls entering service, believing the 'practice of making allowances of 
clothing to the children of able-bodied labourers going into service [which] appears to prevail in many Unions' tantamount to granting 'premiums upon pauper apprenticeships. ${ }^{22}$

Nothing, though, demonstrates the Commissioners' determination to reduce clothing relief so forcefully as their 1839 Minute outlawing the issue of clothing to short-term inmates leaving workhouses, believing that many clad themselves in rags before admission in the knowledge that they would be reclothed on discharge. ${ }^{23}$ Inmates could quit the house after giving three hours' notice, but any requests for parish clothing to take with them had to be considered by the workhouse Guardians at their weekly meetings. In December 1845 the Guardians of the Ledbury workhouse granted the master and matron discretionary powers to clothe a child leaving the workhouse following its birth there. The Commissioners' Secretary, Edwin Chadwick, reminded the Ledbury Guardians they had no authority to delegate such powers prompting local JP, the Revd Edward Higgins, to write to the Commissioners, confident they were not possessed of the full facts. 'On Saturday ... last,' he wrote, 'it being quite dark, and raining in torrents, a naked infant, and cold as ice ... was brought to my door by a labourer and his wife.' The child belonged to a local woman who had left the Ledbury workhouse earlier that day, 'very thinly clad' and seventeen days after giving birth. She had insisted on her right to leave the workhouse, at which point 'the baby clothes were taken from the baby, and the baby was handed over to the mother, naked, whereupon she took off her own flannel petticoat, and a threadbare shawl, and with the infant so covered, she started for her mother's...and on her way exposed the infant.'

The workhouse, Higgins pointed out, was 'a test of destitution' and inmates were 'therefore, to enter it destitute. The infant is born in the house, and of course brings no clothes with it; is it to be sent out naked in all seasons and weather?' Exasperated, he pointed out that the clothing for an infant cost only $2 s$. $6 d$., a 'paltry sum' which was unlikely to 'tempt a woman to immure herself in a workhouse for three weeks and upwards.' The Commissioners were not persuaded; 'the words "any child born in the workhouse",' they said, 'might... be taken to extend to a child of ten years old, and such child might be leaving the workhouse without any parents.' They consented 'to the Guardians authorizing the master to give clothing to infants leaving the 
workhouse with their mothers, and having been born therein, the mother having no clothes for the child,' but cautioned against any liberality that might encourage pregnant women to enter the workhouse to obtain clothes for the expected child. ${ }^{24}$

The Ledbury case prompted revelations of similar incidents and Guardians elsewhere sought guidance and clarification from the Commissioners. Even as correspondence continued between Higgins and Chadwick, early in January 1846, news reached the Commissioners of Elizabeth Butcher who, the previous month, had given birth in a Wiltshire workhouse and left it with her baby who had been 'stripped of the union clothes.' The child was later found drowned. The Commissioners cannot have been pleased when the Coroner reported that, after returning a verdict of wilful murder against Elizabeth Butcher, the jury expressed 'their surprise, that the deceased infant should have been stripped of her clothing, and suffered to leave the workhouse in a state of nakedness, with its mother utterly destitute and unable to shelter it from the inclemency of the weather. They are also grieved to add, that they find other cases of the same character have been similarly treated before quitting the workhouse, by order of the Board.' One witness stated that although Butcher had not applied to the Guardians 'for additional clothing it was admitted by the master that it was generally understood amongst the female paupers, that any such application would have been refused.' Another inmate testified that four years earlier she had given birth in the workhouse and left without clothes for the child having been refused them by the Board. ${ }^{25}$ Two weeks after the Butcher drowning The Times brought the Ledbury case to national attention by reproducing an article from the Worcestershire Chronicle. A note by the Chronicle's editor stated that if the Ledbury Guardians had 'turned the child out of the [workhouse] without a shred of clothes to its back, they would really deserve to be indicted as accessories before the fact.' The new Poor Law, he thought, had 'the property of Medusa's head and turns the hearts of those who assist to put it into operation into stone. ${ }^{.26}$

\section{'SO GENERAL THROUGHOUT THE COUNTRY': THE SPREAD OF CLOTHING SOCIETIES}

The cutbacks in parish relief left the poor dependent on other strategies, in particular charitable assistance. From the late eighteenth century the nature of philanthropy was largely 
determined by what Boyd Hilton terms moderate Anglican evangelicalism. Only a minority of the population, says Hilton, would have identified themselves as Evangelicals, but evangelicalism 'morally...imposed itself on many who were indifferent or even hostile to its religious basis' and in terms of philanthropy, the key term for moderate evangelicals was self-help. ${ }^{27}$ Evangelical thought also deemed social stratification providential and so aimed to relieve rather than eradicate poverty. As Sussex curate the Revd John Barlow explained in 1828, 'It is not in the power of any of us to relieve all who suffer, nor, even were our means of doing good as ample as the kindest heart could wish, would it be proper that we should interfere in every case to avert the penalty intended to discourage extravagance and vice in this present world. ${ }^{28}$

Evangelicals believed eternal salvation was available to all, but had to be earned through the constant avoidance of sin. For the poor this meant proving again and again that they were deserving of assistance, by being grateful and deferential, adhering to good moral conduct and, especially, by demonstrating their willingness to help themselves. For the rich, salvation required them to assist those less fortunate than themselves, but caution was required since, as the Revd Becher in Southwell explained in 1828, 'indiscriminate liberality subverts the Morals and depraves the habits of the Poor. ${ }^{29}$ It encouraged idleness and improvidence, thereby sinfully assisting the recipient on the path to hell and so threatening the salvation of the giver. A particular evangelical target was cash doles since, as the Revd Close of Cheltenham explained, without constant vigilance 'MONEY, or even anything that can be SOLD... will soon be turned into the means of intoxication. ${ }^{30}$ There was no perfect solution to this 'problem,' but a partial remedy lay in helping the poor themselves acquire what they needed, rather than simply handing it over.

An abundance of charitable clothing initiatives proliferated including maternity societies, Dorcas societies, ladies' working parties, needlework guilds and mothers' meetings. Some were long-standing institutions, others innovations, but most increasingly moved away from the free distribution of clothing to, for example, selling it, or the materials, to the poor at cost price. The most significant innovation, particularly in the rural south, was the clothing society. Parish-based, established and managed principally by Anglican clergy, clothing societies supplemented the 
weekly deposits of the poor - usually between $1 d$. and $6 d$. - with premiums subscribed by wealthier neighbours. Premiums varied, but never exceeded the depositor's savings, and were commonly four shillings and four pence - or fifty-two pence, the equivalent of a depositor saving a penny a week for a year. At the end of the year the total sum was laid out on clothing and, sometimes, bedding. The clubs fostered self-respect and a degree of self-reliance, facilitated the management of household income and provided a channel for contact between the classes, since membership by the poor often depended on nomination by a wealthy subscriber - and where it did not the manager retained the right of veto. ${ }^{31}$ They also aimed to reduce the poor rates, a fact made most evident by those societies which refused membership to 'any ablebodied labourer [who] shall consent to receive parochial relief. ${ }^{, 32}$

Clothing societies satisfied the twin demands of self-help and assistance in kind, not cash. The earliest society I have traced was established in Painswick, Gloucestershire, in 1796, recommended in an 1802 Society for Bettering the Condition of the Poor report. ${ }^{33}$ This organisation aimed to 'multiply domestic comforts' and 'promote the cause of morality and virtue' among the poor via the dissemination of information about useful schemes. At this stage it was not greatly concerned with Poor Law reform and although the report mentions two further clothing societies, near Birmingham, few others seem to have been founded before the $1810 \mathrm{~s}^{34}$ But from then, as the debate about Poor Law reform reached a climax, rural clothing clubs mushroomed. By the end of the 1830s there were societies in Berkshire, Buckinghamshire, Devon, Essex, Norfolk, Northamptonshire, Suffolk, Sussex, Warwickshire, Wiltshire and Yorkshire, all of which Blaug identifies as 'Speenhamland counties. ${ }^{35}$ Clothing societies were, then, established predominantly in the rural districts where Poor Law officers 'had come to heed the alarm at the rising burden on the rates' and were looking for ways to check expenditure on outdoor relief. ${ }^{36}$

Jones asks why the poor would spend their own money on clothes 'that may well have been available from the parish.' He concludes that greater opportunity for independent provision was the clothing societies' attraction, citing the Revd Williams of Shalbourne, who stated that the clubs in his parish were 'of little benefit to [the poor], because what they derive from the Club 
now they derived from the parish before the club; and it is no sort of benefit to the poor man any more than it contributes to the support of his independence. ${ }^{37}$ But the point is that the clothes were simply not available from the parish. Jones was assessing two Wiltshire societies in 1831 and 1834 - before, or in the same year as, the new Poor Law was introduced. Williams was giving evidence in 1838 to a Parliamentary Select Committee on the Operation of the new Poor Law - after the attempt to outlaw outdoor relief. Earlier in his evidence Williams had been at pains to emphasise that since the introduction of the 1834 Act the local Poor Law Guardians had consistently refused applications for outdoor relief. The Clothing Club, he said, had been established within the past three years and he cited the restriction on outdoor relief as 'One Cause of it.' Significantly Williams points out that parishioners gained from 'the Club' what they had obtained from the parish 'before the club,' the implication being that 'the Club' had replaced parish provision. ${ }^{38}$ Jones is correct that the Club offered the opportunity to obtain the same items previously supplied by the parish in a more independent fashion, but part of the reason the poor joined it was because they had little option.

By 1833 the Revd Capper in Buckinghamshire, recommending a system of self-help pauper management, thought it necessary to give only a minimal description of a clothing society, 'since this kind of club is so general throughout the country. ${ }^{39}$ Jones emphasises the preponderance of requests for shoes in the relief records of the parishes he studied, and often where a clothing society was instituted so were clubs for coal and footwear operating on identical lines. ${ }^{40}$ Michael Rose claims that from the 1870 s private charity, under the auspices of the Charity Organisation Society was 'to be re-organised...and worked in closer co-operation with the poor law system,' but the evidence provided by clothing societies suggests this was occurring much earlier in the century. ${ }^{41}$

Clothing societies developed at the same time as other self-help institutions, such as friendly societies which spread most rapidly in industrial areas. In the southern counties, where clothing societies proliferated, agricultural labourers showed little inclination to establish friendly societies. Here, as poor rates peaked and clothing societies were introduced, the gentry and clergy took it upon themselves to establish friendly societies for the labourers, run on a similar 
basis to clothing societies, to encourage them to look to their own resources in times of need. ${ }^{42}$ Clothing societies, together with gentry-led friendly societies and penny savings banks, were then, crucial components of a culture increasingly and persistently determined to foster self-help and small savings and equally determined that if the poor could or would not take the initiative themselves, then it must be taken for them.

A second wave of clothing society creation occurred in the third quarter of the century during which London societies appear to have multiplied most rapidly. After 1850 anxiety about the derogatory effects of urban and industrial life increasingly centred on the metropolis. ${ }^{43}$ This was followed by renewed concern about outdoor relief and misdirected philanthropy resulting in a 'Crusade' against outdoor relief. ${ }^{44}$ In 1869 George J. Goschen, President of the Poor Law Board, 'warned metropolitan guardians about the "alarm which might arise on the part of the public" if double distribution persisted involving both statutory relief and charity.' For Goschen 'relief rationalization' could best be organised by a voluntary agency and he looked to the newlyformed Charity Organisation Society to do it. ${ }^{45}$ In fact this Society was never particularly effective, but its formation was a manifestation of an anxious climate convinced of the need once more to curtail indiscriminate philanthropy and encourage the principle of self-help which had gained increased emphasis with the publication of Samuel Smiles' phenomenally successful book on the theme a decade earlier. ${ }^{46}$

In urban areas the clergy saw clothing societies also as an alternative to 'Satan's favourite haunt,' the pawn shop, which the poor regularly used as a means of clothing management, depositing Sunday dress on Monday and redeeming it on Saturday. ${ }^{47}$ The clergy were aided by troops of district visitors who were exhorted to urge upon those they visited the expediency of joining the clothing society, while the society itself provided a good premise for what were often unwelcome visits, since visitors could collect the pennies in the course of their rounds. $^{48}$

'TO CHECK WASTEFULNESS AND VICE': CLOTHING SOCIETY REGULATIONS

Jones questions why depositors 'opted for precisely the same kinds of practical, hard- 
wearing textiles' available from the parish or other charitable sources and concludes that it was due to the poor's rejection of opulence, on moral grounds, in favour of utilitarian clothing which signified 'simplicity, honesty and hard work...fairness, "natural justice" and social responsibility. ${ }^{49}$ But firstly, as I have argued, in many cases these clothes were simply no longer available from the parish, and the poor used clothing societies as replacements to obtain the basic day-to-day clothes a labourer's family required. This was a practicality. Secondly, Jones underplays the restrictions clothing societies placed on the goods they supplied. The societies existed not only to assist with clothing provision, but also to regulate depositors' moral behaviour. The Kettleburgh Penny Clothing Club in 1837, for example, sought 'to promote good Conduct, [and] to check wastefulness and vice.' Societies excluded members if they, or their dependents, were 'guilty of a felony' or 'habitual drunkenness, of tippling in Alehouses...neglect of the Sabbath, thieving, or any gross act of immorality' which might include 'becoming pregnant while unmarried' or having a baby arrive too soon after marriage. Regularity was encouraged through the levy of half-penny fines for non-payment of a weekly instalment, and expulsion, with the forfeit of all monies paid, if the omission continued. ${ }^{50}$

But moral regulation was also attempted through the clothes themselves by restricting the items to be supplied. The goal was to prevent the purchase of 'any smart articles of dress, or finery of any kind.' For the societies' managers, finery among the poor bespoke depravity, inappropriate aspiration and a want of thrift. Societies therefore stipulated that only 'useful and necessary clothing' could be obtained. The Stutton Clothing Club, Suffolk, was typical, and permitted only the purchase of 'Calico, Flannel, Stuffs, Checks, Handkerchiefs, Shawls, Cloaks, Fustian...Waistcoats and Stockings. ${ }^{.51}$ It is true, as Jones states, that many societies offered a 'remarkably diverse' range of textiles, but as with those he found available in the Wiltshire societies, they offered a diverse range of serviceable textiles. ${ }^{52}$ Clad in their practical garments, clothing society members were to be emblems of thrift, piety and industry, whose reward of better clothing for their exemplary conduct was to be an incentive to emulation among their peers. The success of this attempt at social control is, however, doubtful. Since membership often required subscriber nomination, those who joined clothing societies were likely to be the 
'respectable' poor who were already thrifty and industrious. But respectability did not, as Jones implies, inevitably lead to a rejection of 'finery' in favour of 'honest' textiles. Rather, these were all that could be obtained from the clothing societies and items, for Sunday and holiday wear, had to come from other sources, such as the clothes sent home by daughters in service.

Although membership was predicated on respectability, the spectre of pauper fecklessness haunted clothing society management. Fearful that the money might be diverted from its intended purpose, deposits were rarely returned in cash. Instead, many societies issued depositors with a ticket to exchange for goods at a specified local retailer. Edwin Grey, who grew up in a Hertfordshire village during the 1860 s and '70s where, as 'with most other villages there was a...clothing club,' explained that even then the clothes could not be taken home immediately, since they had first to be 'looked over by the Rector's daughters and other local ladies to ensure that all the contents were good, warm, useful articles, and no so-called finery. ${ }^{53}$ Some societies feared that even the tickets might be used to clear 'old debts, \&c.,' and arranged for tradesmen to bring their goods to the village meeting room where, under supervision, depositors made their choice. ${ }^{54}$ In the most cautious societies depositors stated what articles they required and the committee bought and distributed them. As a final safeguard, some managers reserved indefinitely the right to see, on demand, the goods purchased to ensure they had not been sold or pawned. ${ }^{55}$

\section{A SENSE OF 'GRATEFUL ATTACHMENT': CLOTHING SOCIETIES AND CLASS RELATIONS}

The rules and regulations appear repressive and authoritarian, but Jones is nevertheless right in asserting that, through investment of their own money, clothing societies offered the poor a greater degree of independence than parish provision. As the Revd Williams explained to his parishioners, 'If you subscribe to this Society you claim this as a Right, whereas in the other Case you throw yourself upon the Parish. ${ }^{, 56}$ But somewhat paradoxically, the clothing society ideology of what might be termed supervised self-reliance sought to reinforce paternalistic class relations at the same time as it encouraged independence.

In the early decades of the nineteenth century yearly hiring and living-in of agricultural 
labourers declined, particularly in the south-east, increasingly replaced by hiring for the week, day or hour. Under the old system, payment of a guaranteed wage had been made in lump sums once or twice a year, enabling the immediate purchase of necessary items. Under the new system there was no guaranteed annual income and labourers received smaller sums more frequently, which demanded different management. Furthermore, as Keith Snell has shown, in the south of England generally, real wages fell from the early 1800s, while lack of continuity of employment and increasing sexual division of labour, which reduced female employment opportunities in many agricultural areas, led to a further decline in household income. ${ }^{57}$

The change in hiring arrangements together with enclosure and the aspiring gentility of the farmer employers led to physical and social separation between labourer and farmer. The Swing riots of $1830-31$ further widened the gap and were, to wealthier neighbours, evidence of the moral degradation and lawlessness of the agricultural labouring poor ${ }^{58}$ Howkins claims that '[t]he rural poor seemed to many to be completely alienated from their "betters", a separate, secret people, impervious to change and influence.' But as farmers came to recognize the reciprocity between themselves and their labourers, the one unable to work the land without assistance, the other unable to maintain his family without employment, they sought reparation of the rift. The result, says Howkins, was a renewed paternalism, expressed in the selection of key rituals, 'especially those around the gift to revive carefully controlled idyllicist notions of rural social life and order. ${ }^{59}$ By subscribing to clothing societies, farmers and gentry apparently affirmed community hierarchy while assisting the poor and engendering in them contentment, gratitude and deference. For the Revd Barlow in Sussex, clothing societies were the means by which to best 'make the poor feel the value of their own exertions,' while simultaneously inspiring in them a sense of 'grateful attachment' towards their superiors. ${ }^{60}$

The connection between employer as donor and employee as recipient in clothing societies, and the extent to which the societies pervaded and impacted on rural domestic economics, is clarified by an analysis of the depositors and subscribers in one such organisation. In 1851 the Sussex agricultural village of Ripe had a population of 382 of whom 260 were aged eleven and over. ${ }^{61}$ A Clothing Club was instituted in 1854 and attracted forty-two 
depositors, all adults. ${ }^{62}$ Thirty-four of these can be identified in the census material, thirty-two of whom were agricultural labourers or their wives or widows and only one of whom had potentially never been married. ${ }^{63}$ According to the 1851 census, there were fifty family units in Ripe where the head was either an agricultural labourer or his widow and, allowing for the uncertainties caused by members who shared the same name, the thirty-two agricultural-labouring Clothing Club depositors represented a minimum of twenty-seven and a maximum of thirty-two families. So of the total fifty family units, at least fifty-four percent, and possibly sixty-four per cent, had a depositor in the Clothing Club. Of these, only a small minority, who were mostly elderly, had no dependent children. The remainder had between one and eight dependent children or grandchildren. ${ }^{64}$ The majority of Clothing Club depositors were, then, from households where the head was an agricultural labourer or his widow, and where there were dependent children, and over half of the total agricultural-labouring households in Ripe had a Clothing Club depositor.

Of the fourteen subscribers to the Ripe society between 1854 and 1869, ten can be identified. Of these, six were farmers employing, apart from domestic servants, between one and twenty-six persons. The remaining four were an innkeeper, the Rector, the previous incumbent's wife and a landed proprietor. In the case of two subscribers whose identity is uncertain but for whom in each case there are two possibilities, one alternative in each instance is that they were farmers. ${ }^{65}$ In Ripe, then, the majority of non-clerical subscribers were farmer-employers, and the majority of depositors were agricultural labourers. Although it is not certain that the farmers were supporting their own employees, the probability is increased by a 1902 appeal for subscribers. 'In former years,' it said, 'many of the Employers subscribed to the Club, in order that their own work-people might partake of its benefits. ${ }^{.66}$ Anne Digby found that in Norfolk farmers preferred to give perquisites such as 'subscriptions for a clothing club rather than rises in money wages which were difficult to alter later. ${ }^{67}$ In terms of the connection between clothing societies and the reduction of parish relief, it is surely significant that half of the fourteen Ripe Clothing Club subscribers served as Overseers or Guardians of the Poor between $1856-65 .^{68}$ The only depositor to receive outdoor relief during this period was Joseph Townsend who obtained a pair of half boots in 1862 'because he is an imbecile and earns 7/- a week.' Outdoor relief to other 
parishioners was restricted to funeral expenses and the infirm, the unemployed able-bodied being sent to the workhouse. ${ }^{69}$

The same agricultural labourer-depositor/farmer-subscriber pattern prevailed in nearby Rotherfield which, by 1861 , had a population of 3,413 and where approximately thirty-six per cent of all heads of households were clothing society depositors. The figure is lower than in Ripe, but Rotherfield being a larger community had a larger mix of classes and occupations. $^{70}$ The predominance of adult able-bodied labourers among clothing society depositors is significant since although historians have subsequently shown them to be mistaken, it was the perception of the architects of the 1834 Act that they were the main recipients of outdoor relief - and therefore the main targets of the cutbacks. ${ }^{71}$

While the employer-subscriber/employee-depositor model of clothing societies appears to support ideas of the gift as a means of instilling deference and gratitude, in fact the societies may have inspired a lesser degree of 'grateful attachment' than earlier charitable initiatives which required no financial input from the recipient. Anthropologist Marcel Mauss suggested that an unreciprocated gift makes the recipient inferior, because it places them in the donor's debt. ${ }^{72}$ Alan Kidd argues that the nineteenth-century requirement that the recipient be 'deserving' was an attempt to alter the one-way character of the charity relationship by making the condition of being deserving 'a mediated "return" for the charitable gift.' Kidd limits the nature of being 'deserving' to a display of gratitude and deference, long an assumed part of the charitable relationship, unvalued except where it was lacking, but, in the nineteenth century, re-valued as reciprocity. ${ }^{73}$ By requiring the recipient to contribute at least as much as, and usually more than, the value of the gift they received, clothing societies provided a greater degree of reciprocity in the gift relationship and so diminished the deference due. King argues that in the early decades of the century the most ragged poor were not the recipients of parish clothing relief, but those who disdained such assistance and in their struggle for independence were forced to tolerate a very low standard of clothing. ${ }^{74}$ Such individuals may have found the self-help nature of clothing societies more acceptable than the old clothing doles which had to be personally solicited and justified. 


\section{'Clothing Clubs Very RARE': The ABSENCE OF Clothing SOCIETIES IN THE NORTH}

Clothing societies made sense. They were a dependable and semi-independent source of new, serviceable clothing which labourers needed for everyday wear, and, in contrast with the pawnshop and the tally man, offered a premium rather than charging interest, and the goods were generally obtained at a discount. Furthermore, in the hands of a competent needlewoman the materials could be turned into clothes of better quality than those available from other sources such as the slop-shops, selling cheap ready-made garments, or the used-clothing outlets where the garments might already have passed through many owners. ${ }^{75}$ But while clothing societies proliferated in southern agricultural districts and the capital, with some continuing into the 1920 s and '30s, they were much rarer in industrial and mining areas. ${ }^{76}$ Even in northern agricultural areas they appear less common than in their southern counterparts. Witnesses to the Parliamentary Commission investigating the employment of women and children in agriculture in 1842-3, constantly testified to the presence and usefulness of clothing societies in the southern counties, but in Yorkshire and Northumberland they were far fewer and often in decline. Mr. Boyes, Clerk of the Beverley Union, for example, thought benefit clubs were on the increase, but 'Clothing Clubs very rare. ${ }^{.77}$ Occasional examples occur in some northern industrial towns such as Leeds and Manchester, but only one individual who gave evidence to the 1833 Factories Inquiry Commission mentioned a clothing club, and this at precisely the time when their establishment in the southern agricultural districts was reaching its first peak. ${ }^{78}$

There are several possible reasons for this relative absence. Clothing societies were less necessary among the northern industrial poor as they had more varied opportunities to acquire clothing than their southern rural counterparts. These included improved regular markets selling new and used clothing, a greater variety of shops including co-operatives, and more hawkers, tallymen and pawnshops. ${ }^{79}$ Northern textile workers could obtain offcuts and seconds, and embezzled their employers' goods to an extent sufficient to warrant the establishment of a private police force. ${ }^{80}$ Indeed, for the less honest, more opportunistic or simply desperate individual, urban spaces offered more opportunities for begging and theft than rural areas. ${ }^{81}$ 
Furthermore clothing societies' close connection with Poor Law reform and the latter's focus on rural areas probably inhibited their spread in northern industrial areas. Even a decade after the Amendment Act the 1844 Outdoor Relief Prohibitory Order was issued to rural, not urban unions. It took another eight years for an urban equivalent and then, as Robert Humphreys says, the Order 'lacked even the surface stringency of its rural predecessor. ${ }^{182}$ Not until 1875 , and in the wake of the textile industry crises of the 1860s, did the Manchester Board of Guardians take decisive action to limit outdoor relief. ${ }^{83}$

Clothing societies' minimal presence in mining and factory areas may also have been due to higher incomes among workers in those industries, compared with agricultural labourers, which more easily facilitated the outright purchase of clothing. ${ }^{84}$ Also, worker-led friendly societies and, later, trades unions were established earlier in industrial areas than in agricultural districts, suggesting a preference for independent self-help rather than paternalistic schemes. ${ }^{85}$ Additionally, in Manchester spare pennies were far more likely to be devoted to the burial society. This was due to the combination of high infant mortality rates and the 1832 Anatomy Act which permitted the unclaimed bodies of paupers dying in workhouses close to an anatomy school, as in Manchester, to be surrendered for dissection. The Act, says Ruth Richardson, 'appears to have been an important stimulus to the very rapid growth of friendly and burial societies. ${ }^{186}$

In mining areas the population 'was notoriously restless and unsettled' and so lacking the stability the extended deposit period of the clothing society required. ${ }^{87}$ Contemporary sources also cited the lack of paternalism. Parliamentary Sub-commissioner Lichfield claimed in 1842 that in the northernmost counties '[t]he arrival of the pitmen is the signal for the departure of the gentry,' with the result that 'that active benevolence of the higher ranks which induces them to visit the habitations of the working classes; to counsel, guide, and instruct them...are here wholly deficient. ${ }^{88}$ The influence the 'higher ranks' might have exercised, had they stayed, is debatable. Probably more significant, given the prevailing Anglicanism of clothing societies, was the predominance of non-conformity in many industrial and mining areas. ${ }^{89}$ Lichfield noted that the Methodists had 'chiefly, and in several districts exclusively, undertaken the charge of 
providing religious instruction in the collieries' simply because colliery villages were generally established after the parish church had been built and their situation was determined by proximity to the pit, which was often some miles from the church. Methodist chapels, on the other hand, tended to be erected after the villages were established and therefore in the villages themselves, making them more accessible. ${ }^{90}$

Witnesses to an 1842-3 Parliamentary inquiry claimed that dislike of charity was characteristic of northern labourers, but northern independence was not universal especially in the face of poverty. ${ }^{91}$ The mechanisation of textile production and the relative novelty of factory work have made the labourers in that industry the focus of attention, but textile towns harboured more than textile workers. Factory hands accounted for only seven per cent of those relieved by the Manchester and Salford District Provident Society during the severe winter of 1878-9, most of the remaining ninety-three per cent were in the building trade. When Fred Scott, using the criteria employed by Booth in London, investigated Mancunian living standards in 1889 he concluded that half of the sample studied in the Ancoats area, and over sixty per cent of the Salford sample were 'very poor'. ${ }^{92}$ These people needed help as much as the southern agricultural labourers, but few would obtain it from clothing societies although definitive reasons for this have yet to be discovered. Clearly, further research on the forms of clothing provision, and particularly the extent of parish clothing relief, in these regions would be extremely useful.

The popularity of clothing societies in southern rural areas and the capital, as parish clothing relief was withdrawn, is testimony to the poor's ongoing difficulty in clothing themselves and their families. The increase in cheap, mass-produced, ready-made clothing and improved access to retail centres via cheap train, tram and bus fares towards the end of the century made little impact on those caught up in agricultural depression or, for example, mired in the continuing chronic poverty of London's East End.

Clothing societies are evidence also of the determination to ensure that self-help rather 
than outright provision replaced the clothing doles of parish relief. Interestingly, although opposition to the cut-backs in out-relief and the implementation of the new Poor Law are well recorded, there is little documented resistance to self-help clothing schemes. Historians have argued that opposition to change in the Poor Law was based on the poor's assumption of right to relief. Acceptance of self-help schemes does not challenge this argument, but does suggest the respectable poor were flexible about the form relief might take. Many, as beneficiaries of Speenhamland-type systems, were long accustomed to relief being a supplement to, not a replacement for, wages, and were thus equally accustomed to a combined programme of personal contribution and external assistance. Self-help schemes simply put such arrangements on a more formal and reliable footing. Whereas each request for parish clothing relief had to be justified and risked rejection, once accepted into the clothing society the petitioner became a depositor with a guaranteed, if variable, annual return.

Clothing societies helped with the provision of a basic, utilitarian wardrobe, but this could be supplemented with other, perhaps more decorative, items from different sources. Edwin Grey recalled that in his Hertfordshire village during the 1860 s and ' 70 s two travelling shopkeepers from the nearby town of St. Alban's supplied goods to the cottagers which they paid for in weekly instalments. One was a draper, the other dealt in boots and shoes and Grey had 'no doubt that a good bit of the so-called finery so carefully debarred and tabooed from the clothing clubs was bought by the young women from these sources. ${ }^{.93}$ 
${ }^{1}$ Brunel University Library, Working Class Autobiographical Archive, 1:371 Alfred Ireson, pp. 9-

10.

${ }^{2}$ Revd Arthur Young, General View of the Agriculture of the County of Sussex with Observations on the Means of its Improvement (London, 1793), p. 91.

${ }^{3}$ Edward Carleton Tufnell, On the Dwellings and General Economy of the Labouring Classes in Kent and Sussex (London, 1841), pp. 3-4.

${ }^{4}$ Steven King, Poverty and Welfare in England 1700-1850 (Manchester: Manchester University Press, 2000); Steven King, 'Reclothing the English Poor, 1750-1840', Textile History, xxxiii (2002), pp. 37-47.

${ }^{5}$ Peter Jones, 'Clothing the Poor in Early-Nineteenth-Century England', Textile History, xxxvii (2006), pp. 17-37, p. 34.

${ }^{6}$ Ibid., 'Clothing', pp. 30-1. Jones actually refers to clothing clubs rather than societies. The terms 'clothing society' and 'clothing club' were used interchangeably. For continuity, and to distinguish them from commercial clothing clubs, I have used 'society' throughout except where a particular organisation styled itself 'Club'.

${ }^{7}$ Barry Reay includes clothing societies among a range of 'increasingly favoured...low-level savings' schemes, but stops short of asking the reasons for their origination and growing popularity. They are occasionally mentioned among the range of welfare services provided by the Church, and sometimes in connection with the Anglican reforms of the 1830s which encouraged clergy to take a more active pastoral role. Barry Reay, Rural Englands: Labouring Lives in the Nineteenth Century (Basingstoke: Palgrave Macmillan, 2004), p. 79; Alun Howkins, Reshaping Rural England, A Social History 1850-1925 (London: HarperCollins Academic, 1991), p. 74; Nigel Yates, 'An Age of Religious Pluralism 1830-1914', in Nigel Yates, Robert Hume and Paul Hastings, Religion and Society in Kent, 1640-1914 (Suffolk: Boydell Press, 1994), pp. 83-4, 87.

${ }^{8}$ Jones, 'Clothing', p. 29.

${ }^{9}$ Ibid., p. 34.

${ }^{10}$ Eric J. Evans, The Forging of the Modern State; Early Industrial Britain 1783-1870 (Harlow: 
Longman, 1983), p. 402.

${ }^{11}$ Mark Blaug, 'The Myth of the Old Poor Law and the Making of the New', The Journal of Economic History, xxiii (1963), pp. 151-84.

${ }^{12}$ Mark Blaug, 'The Poor Law Report Reexamined', The Journal of Economic History, xxiv (1964), pp. 229-45, p. 231.

13 Population figures given at 'Rotherfield', The Weald of Kent, Surrey and Sussex, http://www.thesussexweald.org/P5.asp?PId=5251Roth, [accessed 20/02/2006].

${ }^{14}$ East Sussex Record Office [ESRO], Rotherfield Request Book [RRB] 1810-11, PAR 465/7/1; RRB 1812-13, PAR 465/7/2; RRB 1820-24, PAR 465/7/5. That there was no significant annual fluctuation in parish clothing provision in the areas Peter Jones examined is implicit, but not explicit.

${ }^{15}$ ESRO, Private Correspondence of Lord Sheffield, SPK P.6.

${ }^{16}$ Jess Steele, Turning the Tide: The History of Everyday Deptford (London: Deptford Forum, 1993), pp. 49, 60, 93.

${ }^{17}$ Lewisham Local Studies Centre [LLSC], Churchwardens and Overseers Committee [COC] Minutes 1809-13, SPD/4/3; COC Minutes 1813-17, SPD/4/4; COC Order Book 1819-25, SPD/4/15; COC Minutes 1822-25, SPD/4/7; COC Minutes 1825-29, SPD/4/8.

${ }^{18}$ LLSC, COC Minutes 1809-13, SPD/4/3; COC Minutes 1813-17, SPD/4/4; COC Minutes 182225, SPD/4/7; COC Minutes 1825-29, SPD/4/8. Clothing supplied for women followed a similar pattern.

${ }^{19}$ ESRO, RRB 1820-24, PAR 465/7/5; RRB 1828-30, PAR 465/7/6: RRB 1830-31, PAR 465/7/7; RRB 1832-33, PAR 465/7/9. Peter Jones also notes the emphasis on clothing young people going into service. Jones, 'Clothing', p. 28.

${ }^{20}$ Return of all Applications addressed to the Poor Law Commissioners on the subject of providing Clothes for Infants born in Workhouses on their being taken out, and of all Answers given, since the passing of the Poor Law Amendment Act, Parliamentary Papers, 1846, XXXVI, 16.

${ }^{21}$ Howkins, Reshaping, p. 74. 
${ }^{22}$ Return of all Applications addressed to the Poor Law Commissioners on the subject of providing Clothes for Infants born in Workhouses on their being taken out, and of all Answers given, since the passing of the Poor Law Amendment Act, Parliamentary Papers, 1846, XXXVI, 16-17.

${ }^{23}$ Ibid., p. 17.

${ }^{24}$ Copy Correspondence between the Board of Guardians of the Ledbury Union and the Reverend Edward Higgins ad the Poor Law Commissioners, Parliamentary Papers, 1846, XVI, 3-5.

${ }^{25}$ Copy Correspondence with the Board of Guardians of the Cricklade and Wootton Basset Union, the Assistant Commissioner of the District, and the Poor Law Commissioners, Parliamentary Papers, 1846, XXXVI, 6, 8, 11, 14.

${ }^{26}$ The Times, 24 January 1846, p. 6.

${ }^{27}$ Boyd Hilton, The Age of Atonement: The Influence of Evangelicalism on Social and Economic Thought, 1795-1865 (Oxford: Clarendon, 1988), pp. 16, 26. Prochaska and Owen also stress the influence of evangelicalism. F. K. Prochaska, 'Philanthropy', in F. M. L. Thompson, The Cambridge Social History of Britain 1750-1950, 3 vols. (Cambridge: Cambridge University Press, 1993), iii, pp. 378-9; D. Owen, English Philanthropy 1660-1960 (London: Oxford University Press, 1965), pp. 93-6.

${ }^{28}$ Revd John Barlow, The Probable Effects of Clothing Societies in Improving the Habits and Principles of the Poor, (London, 1828), p. 19.

${ }^{29}$ Revd John Thomas Becher, The Antipauper System; Exemplifying the Positive and Practical Good, Realized by the Relievers and the Relieved, Under the Frugal, Beneficial, and Lawful, Administration of the Poor Laws, Prevailing at Southwell, and in the Neighbouring District (London, 1828), p. 30.

${ }^{30}$ Anon., The District Visitor's Manual. A Compendium of Practical Information and Facts, for the use of District Visitors (London, 1840), p. 123.

${ }^{31}$ For typical clothing society rules see British Library [BL], 'Kettleburgh Penny Clothing Club, 1837' (n.p.p., 1837). 
${ }^{32}$ Revd F. Litchfield, Three Years Results of the Farthinghoe Clothing Society With a Few Remarks on the Policy of Encouraging Provident Habits Among the Working Classes (Northampton, 1832), p. 5.

${ }^{33}$ The Reports of the Society for Bettering the Condition and Increasing the Comforts of the Poor, Vol III (London, 1802), p. 332.

34 J. R. Poynter, Society and Pauperism: English Ideas on Poor Relief, 1795-1834 (London: Routledge \& Kegan Paul, 1969), pp. 91, 225.

35 'Aldworth Parish Records', Berkshire Record Office, http://www.berkshirerecordoffice.org.uk/collections/summary/pdfs/dp4.pdf, [accessed 16/01/2001]; Revd D. Capper, Practical Results of the Workhouse System, as Adopted in the Parish of Great Missenden, Bucks, (London, 1834), p. 63; 'History of the City and County of the City of Exeter' from White's Devonshire Directory of 1850, GENUKI UK \& Ireland Geneaology,

http: //www.cs.ncl.ac.uk/genuki/DEV/Exeter/ExeterHist1850/index.html, [accessed 9/01/2001]; 'Essex Charities', Rossbret Poor Law Website, http://www/workhouses.co.uk/charities.htm, [accessed 9/02/2001]; Revd George Cotterill, A Pastoral Address to the Members of Clothing Clubs (London, n.d.); 'Norfolk: Earlham' in William White's History, Gazetteer, and Directory of Norfolk 1845, GENUKI UK \& Ireland Geneaology, http://www.uea.ac.uk/ s090/genuki/NFK/places/e/earlham/white1845.shtml, [accessed 24/01/2003]; Senate House, Goldsmiths Library, Hinton Clothing Club, B.834; BL 'Kettleburgh'; BL, 'Rules of the Clothing Club at Stutton' (n.p.p., 1833); BL, 'Rules of the Ubbeston Provident Clothing Society' (Halesworth, n.d.); BL, 'Rules of the Ufford Penny Clothing Club' (Woodbridge, n.d.); Litchfield, Three Years Results; Barlow, Probable Effects, 'Introductory Statement'; S. M. Pinches, 'Charities in Warwickshire in the Eighteenth and Nineteenth Centuries', Unpublished PhD thesis, University. of Leicester (2001), pp. 170-2; Jones, 'Clothing', pp. 29-30; 'Leeds' in Langdale's Topographical Dictionary of Yorkshire, (1822), GENUKI UK \& Ireland Geneaology, http://www.genuki.org.uk/big/eng/YKS/WRY/Leeds/index.html, [accessed 9/01/2001]; Blaug, 'Myth', pp. 158, 178. 
${ }^{36}$ Blaug, 'Myth', p. 167. Kent, where the Deptford clothing society was well established by 1858 , but the year of inauguration is unknown, had the highest poor relief expenditure of nonSpeenhamland counties between 1802 and 1831. Blaug, 'Myth', pp. 178-9.

${ }^{37}$ Jones, 'Clothing', p. 31 (Jones' emphasis).

${ }^{38}$ Report from the Select Committee of the House of Lords appointed to examine the several Cases alluded to in certain Papers respecting the Operation of the Poor Law Amendment Act: Minutes of Evidence, Parliamentary Papers, 1837-38, XIX, 90, 102. There is a further point: when Williams refers to 'the Club' it is not at all certain that he is referring to the Clothing Club. The statement Jones quotes comes in the middle of a discussion of Friendly Societies, also known as Benefit Clubs. The beginning of the statement reads, 'The Benefit Clubs are of little Benefit to them....' Williams has previously explained that parishioners pay $4 \mathrm{~d}$. per month into the Clothing Club and the discussion later continues as follows:

In this Clothing Club do you limit them to a Penny a Week?

Yes, we do....

[W] hat is the Deduction per week from their Means of maintaining their Family for the sake of those Clubs?

The Club is $1 \mathrm{~s} .3 \mathrm{~d}$. a Month, and the other is $4 \mathrm{~d}$. a Month; that would be $1 \mathrm{~s} .7 \mathrm{~d}$. a Month ...

Do they get any thing in the Club towards the Funeral, in the Case of the Death of the Subscriber?

There is a clear distinction between 'the Club', which references to funeral expenses identify as the Friendly Society, and the 'Clothing Club' which is elsewhere distinguished as the 'Penny Club'. Report ... Operation ... Poor Law, pp. 102-3.

${ }^{39}$ Capper, Practical Results, p. 81.

${ }^{40}$ Jones, 'Clothing', p. 22.

${ }^{41}$ Michael E. Rose, 'The Disappearing Pauper: Victorian Attitudes to the Relief of the Poor', in Eric M. Sigsworth, In Search of Victorian Values: Aspects of Nineteenth-century Thought and Society (Manchester: Manchester University Press, 1988), p. 62. 
${ }^{42}$ P. H. J. H. Gosden, The Friendly Societies in England 1815-75 (Manchester: Manchester University Press, 1961), pp. 23-4, 41, 52-3, 60; Martin Gorsky, 'The Growth and Distribution of English Friendly Societies in the Early Nineteenth Century', The Economic History Review, 51 (1998), pp. 489-511, pp. 493-7; Simon Cordery, British Friendly Societies, 1750-1914 (Basingstoke: Palgrave Macmillan, 2003), pp. 49-51; Nicola Sian Reader, 'Female friendly societies in industrialising England, 1780-1850', Unpublished PhD thesis, University of Leeds (2005), pp. 63, 89, 223.

${ }^{43}$ Gareth Stedman Jones, Outcast London, A Study in the Relationship Between Classes in Victorian Society, (New York: Pantheon Books , 1984), p. 12; See also Rose, 'Disappearing', p. 60.

${ }^{44}$ Anne Summers, 'A Home from Home - Women's Philanthropic Work in the Nineteenth Century', in Sandra Burman (ed.), Fit Work for Women (London: Croom Helm, 1979), p. 51; Mary MacKinnon, 'English Poor Law Policy and the Crusade Against Outrelief', The Journal Of Economic History, xxxxvii (1987), pp. 603-25, p. 612.

45 Robert Humphreys, Sin, Organized Charity and the Poor Law in Victorian England (Basingstoke: Macmillan, 1995), p. 5.

${ }^{46}$ Samuel Smiles, Self-Help, With Illustrations of Conduct and Perseverance (London, 1859).

${ }^{47}$ Melanie Tebbutt, Making Ends Meet, Pawnbroking and Working-class Credit (Leicester: Leicester University Press, 1983), p. 113.

${ }^{48}$ Revd Edward L. Cutts, Address to District Visitors (London, n.d.), pp. 16-17.

49 Jones, 'Clothing, p. 32.

${ }^{50} \mathrm{BL}$, 'Kettleburgh'; BL, Rules of the Haveningham Provident Clothing Society (Halesworth, n.d.); Litchfield, Three Years, pp. 4-5; ESRO, Rules of the Uckfield Clothing Society, PAR $496 / 9 / 3 / 1$

${ }^{51} \mathrm{BL}$, 'Kettleburgh'; BL, Rules ... Stutton.

52 Jones, 'Clothing', p. 29.

${ }^{53}$ Edwin Grey, Cottage Life in a Hertfordshire Village: How the Agricultural Labourer Lived and Fared in the Late '60's and the '70's (Harpenden: Harpenden and District Local History Society 
1977), pp. 38-9.

${ }^{54}$ Capper, Practical Results, p. 81.

${ }^{55}$ See, for example, Litchfield, Three Years, p. 5.

${ }^{56}$ Report from the Select Committee of the House of Lords appointed to examine the several Cases alluded to in certain Papers respecting the Operation of the Poor Law Amendment Act: Minutes of Evidence, Parliamentary Papers, 1837-38, XIX, 102-3.

${ }^{57}$ Blaug, 'Myth', p. 171; Reay, Rural Englands, pp. 34-5; K. D. M. Snell, Annals of the Labouring Poor; Social Change and Agrarian England 1660-1900, (Cambridge: Cambridge University Press, 1987), pp. 25 n.24, 29, 129-30, 45, 51-60.

${ }^{58}$ For a full account of the Swing Riots see E. J. Hobsbawm and George Rudé, Captain Swing (London: Pimlico, 1993).

${ }^{59}$ Howkins, Reshaping, pp. 65, 75.

${ }^{60}$ Barlow, Probable Effects, p. 22.

${ }^{61}$ Returns for Ripe in the 1851 Census of England and Wales, The National Archives of the United Kingdom; C. J. Barnes, Sussex (East) Census - 1851 Index (Hastings: C. J. Barnes, 1994).

${ }^{62}$ ESRO, Account Book of Ripe Parish Clothing Club 1854-69, PAR 462/26/1. 'Adults' refers to persons aged eleven and over, the age at which males here entered full-time agricultural labour.

${ }^{63}$ Returns for Ripe...1851 Census; Barnes, Sussex; Returns for Ripe in the 1861 Census of England and Wales, The National Archives of the United Kingdom.

${ }^{64}$ Returns for Ripe...1851; Barnes, Sussex.

${ }^{65}$ ESRO: Account Book ... Ripe, PAR 462/26/1; Returns for Ripe...1851 Census; Returns for Ripe...1861 Cenus; Barnes, Sussex; Rev E. Boys Ellman, Recollections of a Sussex Parson (London, c.1915), pp. 16, 275.

${ }^{66}$ ESRO, Ripe Magazine, December 1902, PAR 462 7/30/1.

${ }^{67}$ Anne Digby, Pauper Palaces (London: Routledge \& Kegan Paul, 1978), p. 22.

${ }^{68}$ ESRO, Vestry Book of the Parish of Rype in the County of Sussex, 1855-1874, PAR 462/12/3.

${ }^{69}$ ESRO, General Ledger of West Firle Union, G12/20/2; ESRO, West Firle Union Minute Book, 
G12/1a/1.

${ }^{70}$ Returns for Rotherfield in the 1861 Census of England and Wales, National Archives of the United Kingdom; ESRO, Rotherfield Clothing Club Book, PAR 465/17/1; ESRO, Rotherfield Clothing Club Report 1867, AMS 1189.

${ }^{71}$ Blaug, 'Myth, p. 177; Rose, 'Disappearing', p. 64.

${ }^{72}$ M. Mauss, The Gift: The Form and Reason for Exchange in Archaic Societies, (London: Routledge, 1990), p. 65; See also Stedman Jones, Outcast, pp. 251-2.

${ }^{73}$ Alan Kidd, 'Philanthropy and the "Social History Paradigm"', Social History, xxi (1996), pp. 180-92, pp. 186-7.

${ }^{74}$ King, 'Reclothing', p. 47.

${ }^{75}$ Only a minority of clothing society goods were supplied ready-made. Whether the remainder was supplied as lengths of fabric, or cut out and ready for sewing is unclear.

${ }^{76}$ The Society in Iford, Sussex, for example, continued until 1931. ESRO, Iford Clothing Club Accounts 1890-1931, PAR 403/26/1.

${ }^{77}$ Reports of Special Assistant Commissioners on the Employment of Women and Children in Agriculture, Parliamentary Papers, 1843, XII, 312.

${ }^{78}$ First Report of the Central Board of His Majesty's Commissioners for Inquiring into the Employment of Children in Factories, Parliamentary Papers, 1833, XX, C2, 14.

79 John Styles similarly noted regional variations in clothing provision in eighteenth-century England, although different from those in the nineteenth. John Styles, 'Clothing the North: The Supply of Non-élite Clothing in the Eighteenth-Century North of England', Textile History, xxv (1994), pp. 139-66, p. 160.

${ }^{80}$ Barry Godfrey, 'Law, Factory Discipline and "Theft", The Impact of the Factory on Workplace Appropriation in Mid to Late Nineteenth Century Yorkshire', British Journal of Criminology, xxxix (1999), pp. 56-71.

${ }^{81}$ For a full discussion of the improved independent clothing opportunities in the industrial north see Tina Vivienne Richmond, "No Finery": The Dress of the Poor in Nineteenth-Century England', Unpublished PhD thesis, University of London (2004), Ch. 4. 
${ }^{82}$ Humphreys, Sin, p. 17.

${ }^{83}$ Alan J. Kidd, and K. W. Roberts (eds.), City, Class and Culture, Studies of Social Policy and Cultural Production in Victorian Manchester (Manchester: Manchester University Press, 1985), p. 55.

${ }^{84}$ E. H. Hunt, 'Industrialization and Regional Inequality: Wages in Britain, 1760-1914, Journal of Economic History, xlvi (1986), pp. 935-66, pp. 953-6, 960-1.

${ }^{85}$ Ibid., p. 857. For trades unions see also Henry Pelling, A History of British Trade Unionism (Middlesex, 1963), Ch. 3. For friendly societies see n. 37 above.

${ }^{86}$ Evans, Forging, p. 154; Ruth Richardson, Death, Dissection and the Destitute (London: Phoenix Press, 2001), pp. 83, 203-7, 275.

87 Raphael Samuel, 'Mineral Workers', in Raphael Samuel (ed.), Miners, Quarrymen and Saltworkers (London: Routledge \& Kegan Paul, 1977), p. 67.

${ }^{88}$ Children's Employment Commission, Appendix to First Report of the Commissioners. Mines, Part I, Parliamentary Papers, 1842, XVI, 533.

${ }^{89}$ There were some Non-conformist clothing societies - Charles Booth, for example, mentioned some run by Wesleyan missions in 1902 - but they do not appear to have been common. C. Booth, Life and Labour of the People in London, Third Series: Religious Influences, 7 vols. (London, 1902-3), vii, pp. 21, 204.

${ }^{90}$ Children's Employment Commission, Appendix to First Report of the Commissioners. Mines, Part I, Parliamentary Papers, 1842, XVI, 533.

${ }^{91}$ Reports of Special Assistant Commissioners on the Employment of Women and Children in Agriculture, Parliamentary Papers, 1843, XII, 335, 337-9.

${ }^{92}$ Kidd and Roberts, City, pp. 50-1.

${ }^{93}$ Grey, Cottage, p. 39. 